\title{
POVERTY REDUCTION THROUGH SELF EMPLOYMENT OF WOMEN : A STUDY ON THENGAMARA MOHILA SABUJ SANGHA (TMSS)
}

\author{
M. A. J. Siddique, M. M. Salehin, J. U. Ahmed ${ }^{1}$ and A. H. M. S. Islam² \\ Department of Rural Sociology, Bangladesh Agricultural University \\ Mymensingh-2202, Bangladesh
}

\begin{abstract}
The study was designed to present the issues of self-employed women of Thengamara Mohila Sabuj Sangha (TMSS) in Shajahanpur Upazila of Bogra district considering their participation in different programmes of TMSS for poverty alleviation. The impact of the study was assessed in terms of economic and social gains accrued by the women's and their family activities. Data were collected randomly from four villages under Shajahanpur Upazila of Bogra district. Sixty members from ten societies consisted of 292 members were selected randomly. The test of mean difference, head count ratio, poverty gap were used towards poverty alleviation. The study revealed that per household annual average income was positively changed. The expenditure and saving pattern indicated a shift of positive attitude towards life and improvement in the standard of living due to womens' contribution. The poverty situations also improved as compared with that of the national level. This small effort is an addition to the knowledge about the essential contribution of the self employed women in different programmes to their role and status in the society which helps to reduce poverty. Finally, some recommendations were also made by the study.
\end{abstract}

Key words : Poverty Reduction, Self employed women, Credit and training program, TMSS (Thengamara Mohila Sabuj Sangha)

\section{INTRODUCTION}

Bangladesh is one of the most densely populated countries of the world with a population of 138.8 million (GOB, 2006). Its density of population is 941 persons per sq. $\mathrm{km}(\mathrm{GOB}, 2006)$ which is one of the highest in the world. The current population growth rate is 1.43 percent per annum $(\mathrm{GOB}, 2006)$. About 76.78 (BBS, 2005) percent of the total population of this country live in the rural areas with the majority living below the poverty line.

The incidence of poverty in Bangladesh is alarming. Among the 177 countries of the world, the position of Bangladesh is 137 in terms of human development index (UNDP, 2006). The recent estimate of the 'head count' ratio is 23 percent for Pakistan, 27

\footnotetext{
${ }^{1}$ Department of Agricultural Economics, Sylhet Agricultural University, Sylhet, Bangladesh

2 Department of Agricultural Economics, Bangladesh Agricultural University, Mymensingh-2202, Bangladesh
} 
percent for Srilanka and 35 percent for India. The head count ratio of poverty in Bangladesh is estimated at 43 per cent for 1988-89 (Salahuddin and Shamim, 1996).

According to the most of the usual indices of quality of life and of economic development, women in Bangladesh are disadvantaged in comparison to men. Women are not only the poorest of the poor; they are also disproportionately represented among the poor. Data from 41 countries, which account for 84 per cent of the total rural population of 114 developing countries, indicate that while in 1965-70 women comprised 57 per cent of the rural poor, by 1988 they accounted for 60 percent. Again between 196570 and 1988, the number of rural women living below the poverty line rose more than the number of rural men living below the poverty line ( 47 percent for women as compared to 30 per cent for men (ILO, 1995).

Poverty is not only a state of deprivation, but also a state of vulnerability. For the female who are half of the population, vulnerability is perhaps, even more central dimension of the poverty experience. Women now comprise the largest part of those living below the poverty line, which are some 41 percent of the population (World Bank, 1990).

Since poverty is still persisting in Bangladesh at a high level, the development efforts undertaken in this country usually focus on poverty alleviation. Poverty alleviation in a country like Bangladesh is a difficult as well as a challenging task. Considering the importance of the problem, both in the pre and post-independent Bangladesh, governments have accorded topmost priority to poverty alleviation programmes especially on rural women. Instead, many non-government organizations came forward in alleviating poverty. TMSS is also such type of non-government organization which tries to reduce poverty of the self-employed rural women. Thus the present study was designed to examine various factors of poverty reduction through different programmes of TMSS.

\section{METHODOLOGY}

In a complete enumeration, required information is collected from each and every element of the population and such a complete survey becomes costly and time consuming. The normal practice, therefore, is to select a sample of representative households which could represent reasonably a true picture of the entire population. After selection of the study area, lists of current beneficiaries (2005-2006) were collected from the TMSS branch offices at Madla and Duplagarihat. The total population of the study was 292 and sample size was 60 (sixty). A random sampling technique was followed in this study to collect sample from the population. Total 60 loanees were selected randomly from four villages of the study area (Table 1). 
Table 1. Selection of respondents from villages under study

\begin{tabular}{c|c}
\hline Name of village & Number of loanees \\
\hline Doglapara & 20 \\
Ghashira & 15 \\
Sajhapur & 15 \\
Vandarpaikha & 10 \\
\hline Total & 60 \\
\hline
\end{tabular}

Source : Field survey, 2006

\section{Analytical techniques}

Some mathematical and statistical techniques were used to test variables used in the study. A brief description of the analytical techniques used is given below.

\section{T-Test}

The $t$-value expresses whether there is a significant mean difference between the two respective variables in the present study.

Let there be $n$ pairs of observations and difference between observations of the ith pair be $\mathrm{d}_{1}$ where

$\mathrm{d}_{1}=\mathrm{x}_{1 \mathrm{i}}-\mathrm{x}_{2 \mathrm{i}} \quad(\mathrm{i}=1,2, \ldots \ldots ., \mathrm{n})$

The sample mean of $d_{1}$ is $\bar{d}=\overline{x_{1}}-\overline{x_{2}}$

Now, on the assumption that $d_{1}$ is an $N\left\{\mu^{(1)}-\mu^{(2)}, 0\right\}$ variate, we are to test the Ho : $\mu^{(1)}-\mu^{(2)}=0$

$$
\mathrm{t}=\frac{\overline{\mathrm{d}}}{\mathrm{s}_{\mathrm{d}} / \sqrt{\mathrm{n}}} \text { With d.f. n-1 }
$$

Thus the more the members of pairs are positively correlated the less is $\mathrm{sd}^{2}$, so that $\mathrm{t}$ becomes more sensitive.

\section{Head count ratio}

The most commonly practiced method for poverty estimation is the head count ratio $(\mathrm{H})$. This ratio was defined as the proportion of the total population that was identified as the poor e.g. the proportion falling below the poverty line expenditure or income. In the present study, this ratio measured how many people were below the poverty line in the study areas. The formula of calculating the head count ratio $(\mathrm{H})$ was:

Where,

$$
\mathrm{H}=\frac{\mathrm{q}}{\mathrm{n}}
$$

$\mathrm{H}=$ Head Count Ratio

$\mathrm{q}=$ population below the poverty line

$n=$ total number of population (Rahman, 1994). 


\section{Poverty gap (PG)}

Another index known as 'poverty gap' (PG) is also used to estimate poverty. This was a better measure of poverty, which measures the degree of poverty by the shortfall of all poor individuals' income from the poverty line. This index tells about the proportion of mean shortfall of income of poor individual (or household) from the poverty line.

In the present study, this ratio measured the shortfall of individual respondents' household income in terms of percentage. The formula for calculating poverty gap (PG) was:

$$
\begin{aligned}
& \mathrm{PG}=\frac{1}{\mathrm{n}} \sum_{\mathrm{i}=1}^{\mathrm{q}}\left[\frac{\mathrm{z}-\mathrm{y}_{\mathrm{i}}}{\mathrm{q}}\right] \\
& \text { Given }\left(z-y_{i}\right)>0, i=1,2,--------------~ q
\end{aligned}
$$

Where,

PG $=$ Poverty gap

$\mathrm{n}=$ Monthly mean poverty line income

$\mathrm{z}=$ Poverty line income

$\mathrm{q}=$ Set of population below the poverty line

$\mathrm{y}_{\mathrm{i}}=$ The monthly income of the poor household/individual (Husain, 1998 and Rahman, 1994).

\section{RESULTS AND DISCUSSION}

\section{Socio-economic profile of the self-employed women beneficiaries of TMSS}

The age of the respondents ranged from 18 to 48 years and above. The average age was 38 years with a standard deviation of 12.242. The highest number (38.33 percent) of the respondents' age were between 28-37, while 21.67 percent were between 38-47 and 8.33 percent were old ( 48 and above). Likewise, level of education of the respondents ranged from 0 to 10. The average score being 5.32 and the standard deviation was 4.89 . The highest proportion (52.54 percent) of the respondents had secondary education compared to 22.03 percent illiterate, 3.39 percent having primary education and 22.03 percent having higher secondary and above education. Similarly, family size of the respondents ranged from 3 to 9 members. The average was 5.01 with a standard deviation of 1.705 . On the basis of their family size, the respondents were classified into three categories: small family (up to 4 members), medium family (5-7 members) and large family ( 8 and above members) (Table 2).

\section{Membership categories of respondents}

In the present study, the length of membership of the respondents was categorized in three groups. Category I, whose length of membership was upto 5 years, category II, whose length of membership was above 5 years to 10 years and category III, whose length of membership was above 10 years for measuring the impact of the TMSS on participants over the period of membership. 
Table 2. Age, education and family size of self employed women

\begin{tabular}{|c|c|c|c|c|c|c|}
\hline Characteristics & Measurement & $\begin{array}{c}\text { Observed } \\
\text { range }\end{array}$ & Categories & $\begin{array}{l}\text { Number of } \\
\text { respondents }\end{array}$ & Mean & $\begin{array}{l}\text { Standard } \\
\text { deviation }\end{array}$ \\
\hline Age & Actual years & $18-70$ & $\begin{array}{c}18-27 \\
28-37 \\
38-47 \\
48 \text {-above }\end{array}$ & $\begin{array}{c}19(31.67) \\
23(38.33) \\
13(21.67) \\
5(8.33)\end{array}$ & 38 & 12.242 \\
\hline $\begin{array}{l}\text { Level of } \\
\text { education }\end{array}$ & Rated score & $0-10$ & $\begin{array}{c}\text { Illiterate }(0) \\
\text { Can sign only } \\
\text { Primary education (1-5) } \\
\text { Secondary education } \\
(6-10)\end{array}$ & $\begin{array}{c}18(30.00) \\
25(41.67) \\
15(25.00) \\
2(3.33)\end{array}$ & 4.89 & 5.56 \\
\hline Family size & Rated score & $3-9$ & $\begin{array}{l}\text { Small family (up to } 4 \text { ) } \\
\text { Medium family (5-7) } \\
\text { Large family (above } 7 \text { ) }\end{array}$ & $\begin{array}{l}25(41.67) \\
20(33.33) \\
15(25.00)\end{array}$ & 5.01 & 1.78 \\
\hline
\end{tabular}

Source : Sample survey, 2006, NB : Figure in the parenthesis indicate percentage

Table 3. Membership categories of respondents

\begin{tabular}{lcccc}
\hline Membership categories & Length of membership & No. of members & Percentages \\
\hline Category I & Upto 5 years & 33 & 55.00 \\
Category II & Above 5 years to 10 years & 25 & 41.67 \\
Category III & Above 10 years & 02 & 3.33 \\
\hline Total & - & 60 & 100 \\
\hline
\end{tabular}

Source : Field survey, 2006

Table 3 shows that among the total respondents, 55.00 percent of the respondents were in the membership category I, 41.67 percent were in category II and 3.33 percent of the respondents were in category III of membership. Thus, the highest of the participants were in the first category.

\section{Demographic characteristics of the respondents' households}

Sixty households from four villages were included in this study. Table 4 shows that total population in the sixty households is 286 whose average family size was 4.77 . The table shows that 28.67 percent of the population was children (of age below 14 years). This was less than the national average of 40.65 percent (BBS, 2004). Here, it may be noted that the lower percentages of children indicated the lower dependency ratio. The rest was splinted between adult male (36.71) and adult female (34.62).

Table 5 shows that the ratio was 1.07. This ratio was higher than that of the national level. The national level sex ratio was 1.05 (BBS, 2004). Two types of ratios were calculated in the study. One was demographic dependency ratio and another was economic dependency ratio. The demographic dependency ratio was the ratio of children and old (above 65 years) to adult men and women between 16 to 65 years. The economic 
dependency ratio was the ratio of children and old (above 65 years) to the actual number of earners. That is, economic dependency ratio is the ratio of economically inactive people to economically active people (Nath, 1990). Here, the table shows that the demographic dependency ratio was 0.56 and the economic dependency ratio was 0.88 in the study areas. Both the levels were smaller than the national level respectively. Another demographic characteristic was the children- women ratio which was the ratio of children upto age 13 years and women in reproductive age of 14-49 years (Nath, 1990).

Table 4. Demographic characteristics of the respondents' households

\begin{tabular}{lcc}
\hline \multicolumn{1}{c|}{ Demographic characteristics } & No. of family members & Percentages \\
\hline Adult male & 105 & 36.71 \\
Adult female & 99 & 34.62 \\
Children & 82 & 28.67 \\
\hline Total & 286 & 100 \\
\hline
\end{tabular}

Source : Field survey, 2006

Table 5. Selected demographic ratios of the respondents' households

\begin{tabular}{lc}
\hline \multicolumn{1}{c|}{ Different demographic ratios } & Value of the ratios \\
\hline Demographic & 0.56 \\
Economic & 0.88 \\
Size of household & 4.77 \\
Sex ratio & 1.07 \\
Children- women ratio & 0.96 \\
Sex ratio of children & 1.05 \\
\hline
\end{tabular}

Note : Several indicators have been calculated from appendix table 1

In the present study areas the child-women ratio was 0.96 which was higher than that of the national level of 0.683 (BBS, 2004). As the sex ratio was higher than that of the national level, child-women ratio was also higher than that of the national level. The sex ratio of children was 1.05 .

\section{Training received from TMSS}

Training experiences can play a vital role for rural women towards participating in income generating activities. It is normally found that training experiences of the women in rural community is very low or even nil. Because most of women do not go out side their house or homestead. As a result inspirations for change do not develop so much. If they are provided with entrepreneurship development training, they can participate in development activities and generate income through these need-based trainings.

Table 6 reveals that 51.67 percent respondents were involved with training programme and 48.33 percent respondent did not receive any kind of training. The highest number of 
respondents received training on agriculture (13.33 percent) and the lowest number of respondents received training on beef fattening ( 5 percent) and nursery or gardening.

Table 6. Training received from TMSS

\begin{tabular}{l|c|c}
\hline \multicolumn{1}{c}{ Name of training } & No. of respondents & Percentage \\
\hline Agricultural training & 8 & 13.33 \\
Pisci-culture & 6 & 10.00 \\
Poultry rearing & 4 & 6.67 \\
Goat and cattle rearing & 6 & 10.00 \\
Beef fattening & 3 & 5.00 \\
Tailoring & 5 & 8.33 \\
Handicrafts & 3 & 5.00 \\
Nursery and gardening & 3 & 5.00 \\
Not received any training & 29 & 48.33 \\
Received training & 31 & 51.67 \\
\hline
\end{tabular}

Source : Filed survey, 2006

\section{Amount of credit received from TMSS}

Micro credit programme empowering the poor by providing them a little amount of credit helps to seek out potential self-improvement capabilities. TMSS started micro financing for reducing the poverty of the poor women by empowering them.

Table 7. Credit received from TMSS

\begin{tabular}{c|c|c|c}
\hline \multirow{2}{*}{ Loan category } & \multicolumn{2}{|c|}{ Respondents } & \multirow{2}{*}{$\begin{array}{c}\text { Average amount } \\
\text { received (Tk.) }\end{array}$} \\
\cline { 2 - 4 } & Number & Percent & 3800 \\
\hline $\begin{array}{c}\text { A } \\
\text { (Upto Tk. 5000) }\end{array}$ & 5 & 8.33 & 8160 \\
\hline B \\
$\begin{array}{c}\text { (Above Tk. 5000 to Tk. 10000) } \\
\text { C }\end{array}$ & 25 & 41.67 & 17500 \\
\hline $\begin{array}{c}\text { (Above Tk.10000) } \\
\text { Total }\end{array}$ & 30 & 50.00 & 29460 \\
\hline
\end{tabular}

Source : Filed survey, 2006

The Table 7 reveals that credit was categorized in three groups. Category A whose amount of credit received was upto Tk. 5000, category B, whose amount of credit received was above Tk. 5000 to Tk. 1000 and category $C$ was above Tk. 10000. In this study, 8.33 percent respondents were in loan category $A, 41.67$ percent respondents were loan category $\mathrm{B}$ and 50 percent respondents were in loan category $\mathrm{C}$. The table shows that 
the highest of the respondents were involved with category $\mathrm{C}$ and average amount of credit received Tk. 17500.

\section{Utilization of average credit which taken from TMSS}

NGOs of Bangladesh are playing a very significant role in the development, especially rural women. The vital instrument is supporting them with micro credit and micro finance is comprehensive and a social programme. Bangladesh is the birth place of micro credit. Micro credit is a major tool of women's self-employment generation as well as mainstreaming in development process. The credit which taken from TMSS, were used various purposes.

Table 8. Use of average credit which taken from TMSS

\begin{tabular}{lcccc}
\hline \multicolumn{1}{c|}{ Purposes } & No. of respondents & $\begin{array}{c}\text { Percentages of } \\
\text { respondents }\end{array}$ & Average amount (Tk.) \\
\hline Homestead gardening & 2 & 3.33 & 2916.67 \\
Field crop production & 10 & 16.67 & 2818.18 \\
Post harvesting & 1 & 1.67 & 5000.00 \\
Poultry raising & 3 & 5.00 & 12200.00 \\
Cattle rearing & 6 & 10.00 & 6700.00 \\
Beef faltering & 2 & 3.33 & 10750.00 \\
Fish culture & 3 & 5.00 & 11166.67 \\
Tailoring & 3 & 5.00 & 2666.67 \\
Handicrafts & 3 & 5.00 & 3666.67 \\
Petty business & 7 & 11.67 & 6250.00 \\
Van/ Rickshaw pulling & 6 & 10.00 & 6666.67 \\
Nursery & 2 & 3.33 & 5000.00 \\
Vegetables cultivation & 2 & 3.33 & 4400.00 \\
Goat rearing & 2 & 3.33 & 6000.00 \\
Family expenditure & 8 & 13.33 & 4000.00 \\
\hline Total & 60 & 100.00 & 90201.53 \\
\hline
\end{tabular}

Source: Field survey, 2006

Table 8 shows that the highest 16.67 percent respondents used credit on field crop production and the lowest 1.67 percent respondents used credit on post harvesting purposes. About 13 percent of them used credit for family expenditure. The highest average amount of money used for poultry raising (Tk. 12200) and the lowest average amount of money used for tailoring (Tk. 2667) which was taken form TMSS.

\section{Impact on per household annual average income of the respondents}

At the initial stage, the respondents were vulnerable because of their landlessness and remorselessness and their income was under the poverty line (poverty line is defined 
here as the value of consumption needed to satisfy minimum subsistence need including food and non-food consumption) (GOB, 2006). The women members invested the credit and training received from TMSS in some productive activities through which they increased their income. The impact of the credit and training on households annual income of the respondents is presented in Table 9.

The table reveals that per household annual average income increased with after membership of the respondents. Here, per household annual average income of respondents was Tk. 13300.58, Tk. 12334.92 and Tk. 25635.50 under agricultural, nonagricultural sources and total income respectively before having membership. Per household annual average income of the respondents were Tk. 30553.33, Tk. 28995 and Tk. 5948.33 under agricultural sources, non agricultural sources and total income respectively after taking membership.

Table 9. Average net annual family income (in Tk.)

\begin{tabular}{lcccc}
\hline \multicolumn{1}{c}{ Sources of income } & Before membership & After membership & T-Value \\
\hline Agricultural Sources & 13300.58 & 30553.33 & $6.75^{* * *}$ \\
Non agricultural sources & 12334.92 & 28995 & $8.675^{* * *}$ \\
\hline Total & 25635.5 & 59548.33 & $9.511^{* * *}$ \\
\hline
\end{tabular}

Significant at $1 \%$ Level

The mean difference for agricultural and non-agricultural sources and total income reveals that there is a significant difference between before and after membership. The result indicates that after and before having membership, per household annual average income was positively changed.

\section{Impact on average annual family expenditure of respondents' household}

Women's contribution to their family expenditure is an important indicator of economic empowerment. In rural Bangladesh, women generally do not have any direct contribution to family expenditure. Women who are in service are exceptions. But the women in small entrepreneur contribute to their family expenditure. In the study area all women spent their income on life sustaining articles such as food, clothes, health care and children's education (Table 10).

Table 10. Average annual family expenditure (in Taka)

\begin{tabular}{lcccc}
\hline Sources expenditure & Before membership & After membership & T-value \\
\hline Foods & 1689.07 & 25805.847 & $15.32^{* * *}$ \\
Others/Non food & 3472.141 & 8396.584 & $10.148^{* * *}$ \\
\hline Total & 20341.211 & 34202.431 & $10.858^{* * *}$ \\
\hline
\end{tabular}

Source : Filed survey, 2006, * Significant at 1\% level 
Table 10 shows that annual average family expenditure on food and non-food items increased Tk. 25805.847 and Tk. 8396.584 respectively after involvement with TMSS. The Table also shows that Tk. 16869.07 of total average expenditure spent on food items before involvement with TMSS and Tk. 3472.141 of total expenditure spent non-food items after involvement with TMSS. Therefore, total expenditure increased after involvement with TMSS. This expenditure pattern indicates a shift of attitude towards life and improvement in the standard of living due to women's contribution to family expenditure. The T-values of annual average expenditure of after and before membership shows that there were highly significant mean differences between them.

\section{Impact on household savings of the respondents}

Savings give strength to the households and increase their capacity of coping with crisis. Savings of women included only money deposited with TMSS. Impact on savings has been discussed in two ways. Table 11 reveals that the average annual savings of Tk. 5294.29 and Tk. 25345.90 were under before and after taking membership with TMSS respectively. It is evident that average annual saving increased after taking the membership of the respondents. The T-Values (6.105) of annual average savings (which is significant at 1 percent level) after and before membership reveals that there were highly significant mean differences between them.

\section{Poverty situation of the selected respondents' households}

To assess the economic impact of the TMSS, overall poverty situation of participants was assessed so that the economic change of the participated households could be examined. Table 11 shows the poverty situation through the co-efficient likes head count ratio and poverty gap. The table reveals that about 28.33 and 21.67 percent households were below the poverty line (poverty line is defined here as the value of consumption needed to satisfy minimum subsistence need including food and non-food consumption) (GOB, 2006) in the year 1996 and 2004 respectively. The head count ratio (calculated in Appendix 2) reveals that about 40.91 and 31.12 percent of the total selected population were below the poverty in the year 1996 and 2004 respectively whereas they were about 47.00 and 42.10 percent in the national level respectively (GOB, 2006). It is observed that the percentage of below poverty line population was lower than that of the national level which indicates an improvement of poverty situation among the respondents' households after becoming member of the societies.

The poverty gap (calculated in Appendix 3) indicates the shortfall of mean in income of individual member of the entire households. In the present study, the poverty gaps of selected population of the respondents' households were 0.180 and 0.108 for the year 1996 and 2004 whereas they were about 0.123 and 0.10 in the national level for the preceding year respectively $(G O B, 2006)$. These gaps were greater than that of the national level.

Finally, it was found that the annual income, women's contribution, savings, land holdings, productive and non-productive assets of the respondents' households increased with the increases of length of their membership. Their poverty situations also improved as compared with that of the national level. 
Table 11. Poverty situations of selected respondents' households

\begin{tabular}{lc|c|c}
\hline Year & $\begin{array}{c}\text { Proportion of households } \\
\text { below poverty line }(\%)\end{array}$ & $\begin{array}{c}\text { Head count } \\
\text { ratio }\end{array}$ & Poverty gap \\
\hline 1996 (before membership) & $17(28.33)$ & 40.91 & 0.180 \\
2004 (after membership) & $13(21.67)$ & 31.12 & 0.108 \\
\hline
\end{tabular}

Source : Filed Survey, 2006

\section{CONCLUSION}

The women respondents received credit and training from the TMSS. They developed different enterprises with the credit and training for increasing employment opportunities and income generation. As a result, positive changes have been occurred in their poverty situations. With the consequences of the changes of these indicators, economic and social status increased substantially. Therefore, the poverty situations improved among the respondents' households. The women under the TMSS in the study areas tried to improve their socioeconomic status by utilizing credit and training in different income generating activities. They achieved a substantial achievement in their activities. The poverty situation of women is constrained by a number of factors. So, along with credit programme, different government and non-government organization should pay attention to remove these constraints.

\section{REFERENCES}

BBS (2004): Statistical Pocket Book of Bangladesh, Bangladesh Bureau of Statistics, Statistics Division, Ministry of Planning, Government of the People's Republic of Bangladesh, Dhaka, Bangladesh.

BBS (2005): Statistical Pocket Book of Bangladesh, Bangladesh Bureau of Statistics, Statistics Division, Ministry of Planning, Government of the People's Republic of Bangladesh, Dhaka, Bangladesh.

GOB (2006): Bangladesh Economic Review, Economic Division, Ministry of Finance, Government of the People's Republic of Bangladesh, Dhaka.

Hossain, M. (1988): “Credit for alleviation of Rural Poverty: The Experience of Grammen Bank in Bangladesh, BIDS, Dhaka.

ILO (1995): Employment and Poverty in Bangladesh. Rural and Urban Informal Sector, Geneva.

Nath, N. C. (1990): Rural Development -12-A Base Line Study. Bangladesh Institute of Development Studies, E-17, Agargaon, Shere-E-Bangla Nagar, Dhaka.

Rahman, P. M. M. (1994): Poverty Issue in Rural Bangladesh. The University Press Limited, Dhaka, Bangladesh.

Salahuddin, K. and Shamim, I. (1996): Rural Women in Poverty: NGO Interventions for poverty, Women for Women, 63/2 Laboratory Road Dhaka.

UNDP (2006): UNDP's Report on Human Development Index, United Nations Development Programmes, Dhaka, Bangladesh.

World Bank (1990): World Bank Development Report, Washington DC. 


\section{APPENDICES}

Appendix Table 1. Demographic characteristics of the respondents' households

\begin{tabular}{|c|c|c|c|}
\hline \multicolumn{2}{|c|}{ Types demographic characteristics } & \multirow{2}{*}{$\begin{array}{c}\text { No. of family } \\
\text { members }\end{array}$} & \multirow{2}{*}{$\begin{array}{c}\text { Percentages } \\
32.52\end{array}$} \\
\hline No aged upto age 15 years & & & \\
\hline No. aged above 65 years & & 10 & 3.50 \\
\hline No. aged among 16 to 65 years & & 183 & 63.99 \\
\hline Demographic dependency ratio & & 0.56 & - \\
\hline No. of earners & & 117 & 40.91 \\
\hline Economic dependency ratio & & 0.88 & - \\
\hline Women of productive age (14-49 & & 85 & 29.72 \\
\hline \multirow{3}{*}{ No. of children under 14 years } & Total & 82 & 100.00 \\
\hline & Male & 42 & 51.22 \\
\hline & Female & 40 & 48.78 \\
\hline Child-Women ration & & 0.96 & - \\
\hline Sex ratio of children & & 1.05 & - \\
\hline \multicolumn{4}{|l|}{ Male $=105+42=147$} \\
\hline \multicolumn{4}{|l|}{$\begin{array}{l}\text { Female }=97+40=137 \\
\therefore \text { Sex ratio }=1.07\end{array}$} \\
\hline Size of household $=\frac{286}{60}=4.77$ & & & \\
\hline
\end{tabular}

Appendix Table 2. The head count ratios of the respondents household

\begin{tabular}{l|c|c}
\hline \multicolumn{1}{c|}{ Items } & $\begin{array}{c}\text { Before membership } \\
(1996)\end{array}$ & After membership \\
\hline Monthly poverty line income (Tk.) & 438 & 631 \\
Population below the poverty line (g) & 117 & 87 \\
Total number of population (n) & 286 & 286 \\
Head count ratio (H) & 40.91 & 31.12 \\
\hline
\end{tabular}

Head count ratio $(\mathrm{H})=\frac{\mathrm{q}}{\mathrm{n}} \times 100$

$$
\begin{aligned}
& =\frac{117}{286} \times 100 \\
& =40.91
\end{aligned}
$$


Appendix Table 3. Poverty gap of respondents households

\begin{tabular}{l|c|c|c|c|c|c}
\hline Year & $\begin{array}{c}\text { Monthly mean } \\
\text { poverty line } \\
\text { income (n) Tk. }\end{array}$ & $\begin{array}{c}\text { Poverty line } \\
\text { income } \\
\text { households } \\
\text { (z) Tk. }\end{array}$ & $\begin{array}{c}\text { Set of population } \\
\text { below the } \\
\text { poverty line (q) }\end{array}$ & $\begin{array}{c}\text { Monthly mean } \\
\text { income of the } \\
\text { poor household } \\
\text { (yi) Tk. }\end{array}$ & (z-yi)/q>0 & $\begin{array}{c}\text { Poverty } \\
\text { gap (PG) }\end{array}$ \\
\hline $\begin{array}{l}\text { Before } \\
(1996)\end{array}$ & 438 & 2511 & 117 & 2876 & 79.11 & 0.180 \\
$\begin{array}{l}\text { After } \\
(2004)\end{array}$ & 631 & 3217 & 89 & 3329 & 68.27 & 0.108 \\
\hline
\end{tabular}

$\therefore$ Poverty gap $(\mathrm{PG})=\frac{1}{\mathrm{n}} \sum_{\mathrm{i}=1}^{\mathrm{q}}\left[\frac{\mathrm{z}-\mathrm{yi}}{\mathrm{q}}\right]$

$$
\begin{aligned}
& =\frac{1}{438} \times 79.11 \\
& =0.180
\end{aligned}
$$

